\title{
The effect of natural disasters on FDI attraction: a sector-based analysis over time and space
}

\author{
Thomas Neise $^{1}$ (i) $\cdot$ Franziska Sohns ${ }^{2}$ (D) $\cdot$ Moritz Breul $^{3}$ (D) . Javier Revilla Diez ${ }^{3}$ (D)
}

Received: 27 February 2020 / Accepted: 6 August 2021 / Published online: 21 August 2021

(c) The Author(s) 2021

\begin{abstract}
Extensive research has addressed the question of why some countries are able to attract a large amount of foreign direct investment (FDI), while others are not. Until now, this research mostly neglected natural disasters as a business risk. In the realm of natural disaster research, some studies have investigated the effect of natural disasters on FDI inflow. However, this research remains overly simplistic and conceals the complexities of the underlying relationship. As such, this article aims to provide a more deciphered perspective by considering variations across economic sectors and the dynamic effect of natural disasters. We apply hybrid panel regressions to a dataset of 181 countries over a period of 13 years across four different economic sectors. The analysis shows that the effect of natural disasters on FDI inflow varies among economic sectors. From a longitudinal perspective, the study finds a positive relationship between exposure to natural disasters and the inflow of FDI within countries 3 and 5 years after an event. Overall, the findings highlight the complex nature of the relationship between natural disasters and FDI and warn against using too simplistic approaches.
\end{abstract}

Keywords Foreign direct investment $\cdot$ Multinational enterprises $\cdot$ Risk $\cdot$ Hybrid panel regression $\cdot$ Sector-specific analysis

Thomas Neise

thomas.neise@uni-osnabrueck.de

Franziska Sohns

F.Sohns@greenwich.ac.uk

Moritz Breul

moritz.breul@uni-koeln.de

Javier Revilla Diez

j.revilladiez@uni-koeln.de

1 Institute of Geography, Osnabrück University, Seminarstr. 19 a/b, 49074 Osnabrueck, Germany

2 Department of Economics and International Business, University of Greenwich, Old Royal Naval College, Park Row, Greenwich, London SE10 9LS, UK

3 Institute of Geography, University of Cologne, Albertus-Magnus-Platz, 50923 Cologne, Germany 


\section{Introduction}

In recent decades, rising volumes of foreign direct investment (FDI) have fundamentally shaped global development (Dicken 2015). Across the globe, the amount of FDI increased more than tenfold between 1991 and 2016, yet the inflow of FDI is unequally distributed in spatial terms. Although some emerging countries, such as China or Brazil, and even some developing countries, such as Mozambique or Zimbabwe, were able to increase the amount of their FDI inflow between 2000 and 2016 (UNCTAD 2017a), most developing countries still lack substantial FDI inflow, which reduces their ability to accelerate their economic development. Hence, extensive research has addressed the question as of why some countries are able to attract a large amount of FDI, while others are not. In this context, the OLI (Ownership, Location, Internalization) model by Dunning (1977) has been most influential in providing a helpful framework to study the location determinants for FDI inflow. Research building on this model has revealed that macroeconomic (e.g., trade openness, market size) and institutional factors (e.g., regulatory quality, corruption control) determine the attractiveness of countries as destinations for FDI (e.g., Economou et al. 2017; Krifa-Schneider and Matei 2010).

However, FDI attraction is not only influenced by macroeconomic and institutional factors. Business operations and investments can also be impacted by the occurrence of risks in the host region. In this respect, natural disasters, such as earthquakes, droughts, storms, and floods, can cause damage to production sites and burden the economy of host countries, due to the destruction of infrastructure and assets (e.g., machinery or farmland). Over the last decades, economic losses due to natural disasters have increased worldwide (Swiss Re Institute 2017). Climate change tends to increase the occurrence and magnitude of natural disasters (e.g., storms and floods), as well as the economic losses in many regions of the world (IPCC 2018). As natural hazards put economies at risk, it can be assumed that multinational enterprises (MNEs) increasingly consider the occurrence and severity of natural disasters when making investment decisions, potentially impeding the attraction of long-term investment (Keen et al. 2003). Interestingly, the occurrence of natural disasters has not yet explicitly found its way as a location determinant for FDI inflow into the OLI literature.

To date, only a small number of studies attempted to assess the relationship between FDI inflow and natural disasters (e.g., Anuchitworawong and Thampanishvong 2015; Escaleras and Register 2011; Khan et al. 2020). While providing preliminary insights that support the expected negative effect of natural disasters on FDI inflow, the applied perspective remains overly simplistic and therefore conceals the complexities of the underlying relationship. Existing studies take either a one-country perspective (cf. Anuchitworawong and Thampanishvong 2015), do not distinguish between business sectors, or take a purely cross-sectional perspective (cf. Escaleras and Register 2011). We argue that the relationship between natural disasters and FDI inflow requires a more differentiated assessment.

This article, therefore, aims to improve the understanding of the complex relationship between natural disasters and FDI inflow by considering variations across economic sectors and the longitudinal character of the effect of natural disasters. First, investment decisions across various economic sectors are influenced by sector-specific features such as sunk costs, demand volatility, and the resiliency of supply chains (Linnenluecke and Griffiths 2015; Wilbanks et al. 2007; World Bank 2020) and, as such, follow different rationales after natural disasters. Second, existing studies (e.g., Crespo Cuaresma et al. 2008; Skidmore and Toya 2002) on the impact of natural disasters on economic growth identified the 
process of creative destruction leading to an increase of economic activity in the aftermath of disasters. Research on the interplay between natural disasters and institutions shows that the occurrence of natural disasters can initiate learning processes in the country, meaning that institutions and firms can adapt to the exposure to natural disasters (Neise et al. 2018; Solecki et al. 2017).

This suggests that a longitudinal perspective is needed to study the relationship between natural disasters and FDI inflow appropriately. In order to achieve this aim, we apply hybrid panel regressions for a dataset of 181 countries over a period of 13 years (2003-2015) across four different economic sectors (manufacturing, construction, tourism, creative industries) marked by different features relevant for the degree of exposure to natural disasters.

The remainder of the paper is organized as follows: In the second section, a literature review outlines the role of FDI for economic growth, the underlying determinants that influence FDI flows, and the economic consequences of natural disasters. In the third section, the datasets, empirical framework, and methodology are explained. The fourth section presents and discusses the results. Section 5 summarizes the main findings of the article and discusses their conceptual and theoretical value.

\section{Literature review}

\subsection{Foreign direct investment: economic growth and determinants}

FDI is one of the major vehicles of economic globalization. The global volume of FDI increased from 154 billion USD in 1991 to 1.7 trillion USD in 2016 (UNCTAD 2017a). FDI not only represents the main external source of finance for developing economies (UNCTAD 2017b) but is also associated with creating positive externalities (Alfaro et al. 2010; Damgaard 2011; Görg and Greenaway 2004) and employment effects (McDonald et al. 2003), which contribute to economic growth in host regions. As only the most productive companies are typically engaged in FDI deals, they transfer superior technology and knowledge into the host region (Helpman et al. 2004). Productivity spillovers to firms in the host region can occur via labor mobility (Driffield and Taylor 2000), increasing competition (Blomström and Lipsey 1989) and demonstration effects, i.e., via the imitation of skills and technology (Girma et al. 2001).

However, the positive effects induced by inbound FDI cannot be taken for granted, as the equivocal empirical evidence in the literature suggests (e.g., Alfaro et al. 2004; Bwalya 2006; Tondl and Forneo 2010; Wang and Wong 2009; Yasar and Morrison Paul 2007). Research shows that positive externalities depend on conditions in the host region, such as the absorptive capacity of the local industry (Alfaro et al. 2010; Girma and Wakelin 2002). In addition, the nature of the particular FDI is relevant for its regional economic outcome in the host region. In this respect, a study by Wang and Wong (2009) indicates that the inflow of greenfield FDI (i.e., investments in new facilities) has a significantly positive effect on GDP growth in the host country, whereas mergers and acquisitions exhibit a negative causality. In addition, McDonald et al. (2003) show that the creation of employment is rather a result of greenfield FDI than mergers and acquisitions.

Although the inflow of FDI is no guarantee for economic growth in the host regions, as this brief overview demonstrates, its potential merits have turned FDI into an important component of the economic growth strategy of many countries, such as China (Zhang 
2001) or East European countries (Bhandari et al. 2007). FDI flows, however, are unequally distributed across space, and a large amount is concentrated in only a few regions (see Fig. 1). The two largest host economies for FDI, the USA, and the UK, amount for $37 \%$ of the global FDI inflows in 2016 (UNCTAD 2017a). In contrast, other regions struggle to attract substantial FDI in their endeavor for economic development. To understand the geographic distribution of FDI inflows, extensive research has attempted to explore factors that foster or hamper FDI attraction. In this context, the OLI model by Dunning (1977) provides a helpful theoretical framework to explain why and where firms conduct FDI. Dunning (1977) argues that ownership (O), internalization (I), and locational (L) advantages must be present for FDI to occur. In the case, a firm only benefits from ownership and internationalization advantages, while locational advantages are absent, the firm rather chooses to export the product, instead of investing in a particular location. While the first two determinants are firm-specific, locational advantages refer to country-specific conditions and determine where a firm chooses to invest. As the range of variables that have been investigated so far in regard to locational advantages is quite extensive, we focus in our literature overview on the most commonly used macroeconomic factors, which are the size of the host country's market, the degree of openness of its economy, and its institutional settings (e.g., Economou et al. 2017; Jadhav and Katti 2012; Resmini 2000).

A major reason for companies to invest abroad is to develop new market opportunities. The market size of the host economy is, therefore, a decisive macroeconomic factor that affects investors' decisions (Resmini 2000). Empirical studies confirm the positive influence of market size on the volume of FDI inflow (e.g., Alam and Shah 2013; Economou et al. 2017).

The openness of the economy is regarded as another important determinant of FDI attraction. The literature argues that foreign investors are encouraged by a liberal trade regime in the host country because MNEs tend to produce not only for domestic but also for international markets (Bevan and Estrin 2004). Most studies confirm this positive relationship (e.g., Economou et al. 2017; Krifa-Schneider and Matei 2010). However, some scholars also find mixed results depending on the statistical model applied (Alam and Shah 2013).

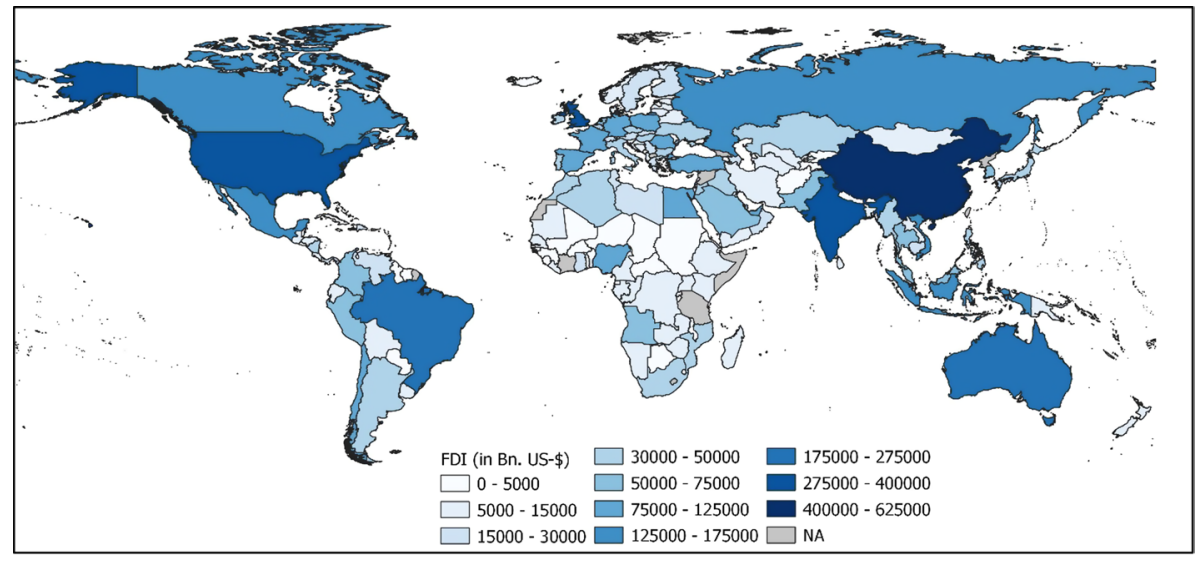

Fig. 1 FDI inflow in billion US-\$ worldwide 2003-2015 (data: Own calculation based on fDi-markets 2016) 
The literature also highlights the importance of the institutional setting for attracting FDI. Poor institutions, such as weak law enforcement or inadequate government effectiveness, lead to additional costs (e.g., hidden costs in terms of corruption, delays) and create uncertainties. As FDI is associated with sunk costs, MNEs take the institutional environment carefully into consideration, as a particular business risk, before making the investment decision (Blonigen 2005; Chen 2017; Jadhav and Katti 2012; Liu et al. 2016). A study by Krifa-Schneider and Matei (2010) on 33 developing and transition countries confirms these arguments. Their findings suggest that a reduced political risk and favorable business conditions in the host country foster FDI attraction. Likewise, Gedik (2013) reveals in a study on eleven OECD countries that political and institutional stability has a positive impact on inbound FDI. Asiedu (2006) and Cleeve (2008) confirm the negative impact of the degree of corruption on FDI inflows for a sample of Sub-Saharan African countries. However, empirical evidence regarding the impact of corruption is equivocal. Al-Sadig (2009), for instance, finds a negative relationship between the level of corruption and FDI inflows. After controlling for the quality of institutions in the host country, however, the effect becomes insignificant.

Apart from risks caused by the institutional setting, business risks can also be created by natural disasters, as we will outline in the next section.

\subsection{Impact of natural disasters on foreign direct investment}

In recent years many severe disasters have caused extensive damage to infrastructure, businesses, and livelihoods worldwide. Between 2002 and 2016 the Tohoku Earthquake (2011), Hurricane Katrina (2005), the Sichuan Earthquake (2008), Hurricane Sandy (2012) and the Thailand floods (2011) were the five most costly natural disasters. However, they account for just $22 \%$ of all economic losses in this time period (Munich 2017). In contrast, smaller natural disasters, often not measured in terms of economic losses, affect several regions of the world much more regularly (particularly in Africa, Asia, and Oceania) (see Fig. 2; CRED 2021; Hallegatte 2014).

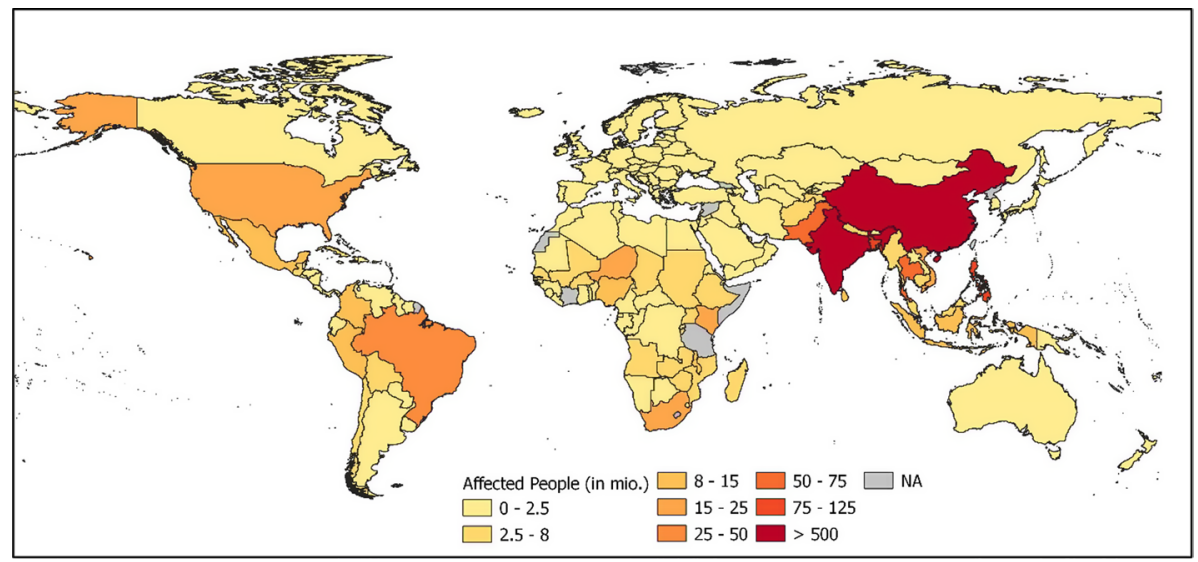

Fig. 2 People affected by natural disasters worldwide 2002-2014 (data: Own calculation based on CRED 2021) 
A comparison of Figs. 1 and 2 shows that many host countries of FDI are exposed to natural disasters. For instance, both emerging economies, such as China, India, and Brazil, and high-income countries, e.g., the USA, attract a high amount of FDI but also suffer from high exposure to natural disasters.

In order to discuss the effect of natural disasters on FDI inflows, we start with the scientific discourse about the impact of natural disasters on economic development in general that emerged since the 1990s. This literature strand predominately focuses on the GDP and the national income as independent variables, aiming to measure the effect of natural disasters on economic development. One strand of the literature deals with the short-term effects of natural disasters on GDP growth. The most prominent study is that by Albala-Bertrand (1993), which indicates a positive impact of natural disasters on GDP growth (see also Loayza et al. 2012; Skidmore and Toya 2002). However, other scholars (e.g., Felbermayr and Gröschl 2014; Klomp and Valckx 2014; Noy 2009) find a negative correlation. The second strand of the literature looks at the long-term effects of natural disasters on economic development. For instance, the seminal work by Skidmore and Toya (2002) reveals that natural disasters-in line with the Schumpeterian 'creative destruction'-lead to increasing GDP because old stocks (e.g., machines) are replaced by newer items (Crespo Cuaresma et al. 2008). In contrast, Noy (2009) proves the opposite. Hence, the results can be seen as ambiguous.

These two strands of the literature focus primarily on macroeconomic factors that might be affected by natural disasters. In line with these studies, it is typically stated that higher-income countries are better able to compensate for the damage caused by natural hazards, i.e., these countries are more resilient to natural disasters than lowincome countries (Hallegatte 2014).

Apart from its influence on economic growth in aggregate terms, natural disasters can also be assumed to influence the ability of host countries to attract FDI, as natural disasters are regarded as a business risk by MNEs, threatening their business operations and assets invested (Khan et al. 2020). For instance, $48 \%$ of the executives interviewed in an UNCTAD survey are of the opinion that natural disasters will lead to a decrease in the global FDI volume (UNCTAD 2017b). Thus, it can be assumed that MNEs also take the occurrence and severity of natural disasters into consideration when making location decisions. Accordingly, the occurrence of natural disasters can be seen as a country's locational disadvantage, as defined by Dunning (1977) in the OLI model, potentially hampering FDI.

However, studies that focus explicitly on the relationship between FDI and natural disasters are scarce. An exception to this is a study conducted by Escaleras and Register (2011) which tests the relationship between FDI and natural disasters for 94 countries between 1984 and 2004. The results reveal that natural disasters have a significantly negative correlation with FDI inflows. These results are confirmed by Cunado and Ferreira (2014) who studied the influence of flood events in 135 countries between 1985 and 2008 on FDI inflow. Anuchitworawong and Thampanishvong (2015) confirm the negative impact of natural disasters on FDI inflows for their case study on Thailand. The recent study by Khan et al. (2020) also supports the negative impact of natural hazards on incoming FDI to countries included in the Chinese Belt and Road initiative. However, Wang et al. (2021) show that FDI inflow increases in the year subsequent to a disaster event, but its ratio of GDP decreases. The authors argue that MNEs may only replace damaged production facilities but tend to avoid further expansion due to deteriorating business conditions. These preliminary insights suggest the following effect: 
H1 The more a country is affected by natural disasters, the less it attracts FDI.

However, we also argue that existing studies apply an overly simplistic perspective on the relationship between natural disasters and FDI inflow, by disregarding the fact that the impact of natural disasters on FDI inflows might vary across different economic sectors. A comprehensive, sector-based analysis for 68 developing countries conducted by Loayza et al. (2012), for instance, shows that the economic effect of natural disasters differs according to the economic sector. The study shows that while storms have a positive growth effect on GDP in manufacturing, the growth effect on GDP in agriculture is negative. Hallegatte (2014) and Rose (2009) find that the construction sector experiences growth after the occurrence of a natural disaster due to the resulting surge in demand. Hence, we argue that it requires a more differentiated assessment of the relationship between natural disasters and FDI inflow to reveal its complexities.

Therefore, we aim to analyze a set of different economic sectors. For illustrative purposes, we focus on the FDI inflow in four different sectors, namely construction (e.g., real estate and building, construction materials), manufacturing (e.g., production or processing of goods), tourism (e.g., hotels, entertainment), and creative industries (e.g., digital media, education, music, market research). We selected these sectors because they are marked by different characteristics, such as the degree of spatial fixity or market demand dynamics, leading to expected differences in how a natural disaster might impact the sector-specific FDI inflows. In this regard, we used the construction sector as an example to analyze whether FDI in disaster-prone areas takes place mainly for reconstruction (Hallegatte 2014). Moreover, we chose the manufacturing sector, as it is highly susceptible to supply chain disruptions that can create high economic losses (Hallegatte 2014; Wilbanks et al. 2007; World Bank 2020). Hence, it can be expected that investors might avoid investment in disaster-prone locations. In addition, the tourism sector was chosen, as this is typically characterized by very fragile demand after disasters (Tsai et al. 2016). Moreover, creative industries were selected as an example of a typical footloose sector in which disaster proneness can be offset more easily because the sunk costs are relatively low. Consequently, natural disasters are not expected to represent a particular business risk that determines the location choice for investment in creative industries. Accordingly, we derive the following hypothesis:

H2 The effect of natural disasters on FDI attraction varies among different economic sectors.

Despite the revealed negative effect of natural disasters on FDI, studies that follow a longitudinal approach show different effects over time. For instance, Escaleras and Register (2011) confirm the negative effect of natural disasters on FDI also for disaster events 5, 10, and 25 years earlier. Moreover, existing research on the interplay between natural disasters and institutions stresses the longitudinal nature of the effects of natural disasters. The recent study by Nohrstedt et al. (2021) has analyzed whether the severity and frequency of natural disaster events in 85 countries over 8 years results in a change of disaster risk reduction policy. The study finds that disaster events do not lead to a change of the disaster risk reduction policies. In contrast, case studies indicate that natural disaster events can act as a trigger for strengthening formal institutional environments in these countries in order to improve the adaptation and relieve the harm by natural disasters (Neise et al. 2018; Solecki et al. 2017). For instance, the Indonesian government improved the legislation and 
organization on disaster risk reduction after two large disasters (i.e., Boxing Day Tsunami and the Yogyakarta earthquake) (Djalante and Garschagen 2017). Similarly, it has been observed that MNEs remain in their disaster-prone location and adapt to these challenges. To give an example, MNEs in Jakarta improved their business routines and invested in adaptation measures, such as back-up facilities and the strengthening of building fabric, instead of relocating (Neise and Revilla Diez 2019). Thus, the occurrence of natural disasters can initiate learning processes in the country to cope with the challenges and prevent MNEs from holding back their investment. A cross-sectional analysis is incapable of taking into account these processes. It, thus, requires a longitudinal perspective in order to consider these learning mechanisms.

H3 The longitudinal effect of natural disasters on the attraction of FDI significantly differs from the cross-sectional effect.

\section{Methods}

\subsection{Data and empirical framework}

For the empirical investigation, we combined data from the EM-DAT database (CRED 2021), the fDi-markets database (fDi-markets 2016), and the World Bank (2017a, b). The fDi-markets database, provided by the Financial Times, collects notifications by the media, financial information vendors, market and publication companies, and industrial associations, making the database the most comprehensive online database on cross-border greenfield investments. We decided to use this database based on the assumption that the inflow of greenfield FDI has a significantly positive effect on GDP and employment growth in the host country (McDonald et al. 2003; Wang and Wong 2009). Two strengths of the fDi-markets database are that it contains the value of FDI projects in million USD for 203 countries from 2003 until 2015, and that it reports FDI by economic sectors (Burger et al. 2013). We used the information provided by the fDi-markets database to generate five independent variables by adding up the value of the individual FDI projects per country and year: overall FDI inflow, FDI inflow in construction, manufacturing, tourism, and creative industries (see Table 1; see Table 5 for a taxonomy of the sectors).

The chosen approach enables us to compare the estimated effects of the independent variables on FDI inflow in different industries and allows cross-country, time-serial, and sector-specific analyses.

To operationalize natural disasters as the main independent variable of interest, we used the EM-DAT database (CRED 2021), which continuously collects data on disaster events with at least one of the following criteria: ten or more people were reported killed, a hundred or more people were reported affected, a state of emergency was declared, or international assistance was called. The database is updated on a daily basis using information on natural disasters from different sources, including UN agencies, governments, the International Federation of Red Cross and Red Crescent Societies, insurance companies, research institutes, and press agencies. The database includes information about the country in which the disaster occurred, the type of disaster according to a pre-defined classification, the date when the disaster occurred, the number of dead or missing people, the number of people who were injured or become homeless as a direct result of a disaster or were affected (i.e., requiring basic survival needs such as food, water, shelter, sanitation, 
Table 1 Dependent variables-FDI inflow by business sector. Source: Own calculation based on fDi Markets, a service from The Financial Times Limited, 2016

\begin{tabular}{|c|c|c|c|c|c|c|}
\hline Variable & & Mean & Std. dev & Min & Max & Observations \\
\hline \multirow[t]{3}{*}{ Overall } & Overall & 2729.42 & 6436.33 & 0 & $70,702.73$ & $N=2307$ \\
\hline & Between & & 5486.58 & 0 & $48,040.04$ & $n=181$ \\
\hline & Within & & 3314.33 & $-19,388.97$ & $41,334.63$ & $\mathrm{~T}-\mathrm{bar}=127.459$ \\
\hline \multirow[t]{3}{*}{ Construction } & Overall & 403.57 & 1578.07 & 0 & 40,009 & $N=2307$ \\
\hline & Between & & 885.76 & 0 & 7071.49 & $n=181$ \\
\hline & Within & & 1304.06 & -4471.06 & $37,328.50$ & $\mathrm{~T}-\mathrm{bar}=127.459$ \\
\hline \multirow[t]{3}{*}{ Creative industries } & Overall & 32.72 & 127.35 & 0 & 2541.30 & $N=2307$ \\
\hline & Between & & 102.46 & 0 & 806.57 & $n=181$ \\
\hline & Within & & 74.75 & -693.45 & 1767.45 & $\mathrm{~T}-\mathrm{bar}=127.459$ \\
\hline \multirow[t]{3}{*}{ Manufacturing } & Overall & 1689.09 & 5301.43 & 0 & $76,544.82$ & $N=2307$ \\
\hline & Between & & 4805.82 & 0 & $50,319.21$ & $n=181$ \\
\hline & Within & & 2170.10 & $-22,504.32$ & $29,369.19$ & $\mathrm{~T}-\mathrm{bar}=127.459$ \\
\hline \multirow[t]{3}{*}{ Tourism } & Overall & 174.07 & 657.34 & 0 & $14,684.30$ & $N=2307$ \\
\hline & Between & & 473.88 & 0 & 5206.26 & $n=181$ \\
\hline & Within & & 452.57 & -3549.36 & 9652.11 & T-bar $=127.459$ \\
\hline
\end{tabular}

and medical assistance) during the period of emergency, as well as the amount of damage to property, crops, and livestock (CRED 2021). This makes the EM-DAT database one of the most comprehensive database, covering global disasters.

Although the number of disaster events or economic losses attributed to a natural disaster are the most commonly used indicator for analyzing the effect of natural disasters (e.g., Raschky 2008; Schumacher and Strobl 2011), we used the sum of people who were killed, missing, injured, became homeless, or were in other ways affected by a natural disaster as a proxy ('number of people affected (in 1000)' to assess the severity of disasters (Altay and Ramirez 2010). Other studies have shown the suitability of this indicator (see Cavallo et al. 2013; Loayza et al. 2012; Noy 2009). The assessment of economic losses is often inaccurate, particularly in developing countries (Hallegatte 2014), and people affected by a disaster better reflect potential disruptions related to a reduced labor force or lower labor productivity.

In addition, following the theoretical discussion on decisive factors of FDI attraction, we employed data about governance quality from the World Bank (2017b). Referring to the literature (Asiedu 2006; Cleeve 2008; Gedik 2013), we incorporated the variables 'government effectiveness' and 'regulatory quality' as well as the variable 'control of corruption' into the model, all of which are measured in units of a standard normal distribution, ranging on a scale from -2.5 to +2.5 (World Bank 2017b). In this respect, the variable 'control of corruption' describes the extent to which public power is used for private gain, while the variable 'government effectiveness' captures the quality of public and civil services, the quality of policy implementation, and the credibility of the government's commitment to such policies. In addition, the variable 'regulatory quality' reflects the government's ability to implement regulations that permit and promote private sector development (see Table 2; World Bank 2017b).

Following the theoretical discussion on decisive macroeconomic factors of FDI attraction (Resmini 2000; Felbermayr and Gröschl 2014), we also controlled for the effect of 
Table 2 Independent variables-people affected by natural disasters, macroeconomic indicators, governance quality, and interaction effects. Source: Own calculation based on CRED 2021 and World Bank $(2017 \mathrm{a}, \mathrm{b})$

\begin{tabular}{|c|c|c|c|c|c|c|}
\hline Variable & & Mean & Std. dev & Min & Max & Observations \\
\hline \multirow{3}{*}{$\begin{array}{l}\text { Number of people affected } \\
\quad \text { (in 1000) }\end{array}$} & Overall & 1193.47 & $12,783.26$ & 0 & $342,026.50$ & $N=2307$ \\
\hline & Between & & 9409.18 & 0 & $119,871.00$ & $n=181$ \\
\hline & Within & & 8578.78 & $-91,126.68$ & $302,650.60$ & T-bar $=12.75$ \\
\hline \multirow[t]{3}{*}{ Population (in 1000) } & Overall & $37,189.32$ & $137,452.30$ & 64.56 & $1,364,270.00$ & $N=2307$ \\
\hline & Between & & $136,442.20$ & 65.03 & $1,323,661.00$ & $n=181$ \\
\hline & Within & & 5772.68 & $-67,939.88$ & $137,162.30$ & $\mathrm{~T}-\mathrm{bar}=12.75$ \\
\hline \multirow{3}{*}{$\begin{array}{l}\text { GDP per capita (in } 1000 \\
\text { USD PPP) }\end{array}$} & Overall & 16.269 & 19.224 & 0.406 & 141.947 & $N=2307$ \\
\hline & Between & & 18.793 & 0.554 & 116.020 & $n=181$ \\
\hline & Within & & 4.406 & -32.184 & 72.223 & $\mathrm{~T}-\mathrm{bar}=12.75$ \\
\hline \multirow[t]{3}{*}{ Trade as $\%$ of GDP } & Overall & 92.02 & 54.24 & 0.17 & 455.42 & $N=2307$ \\
\hline & Between & & 51.72 & 8.15 & 396.21 & $n=181$ \\
\hline & Within & & 15.74 & -37.07 & 243.11 & T-bar $=12.75$ \\
\hline \multirow[t]{3}{*}{ Regulatory quality } & Overall & -0.01 & 0.97 & -2.68 & 2.23 & $N=2307$ \\
\hline & Between & & 0.96 & -2.06 & 1.92 & $n=181$ \\
\hline & Within & & 0.18 & -1.38 & 0.81 & $\mathrm{~T}-\mathrm{bar}=12.75$ \\
\hline \multirow[t]{3}{*}{ Government effectiveness } & Overall & -0.01 & 0.98 & -2.25 & 2.43 & $N=2307$ \\
\hline & Between & & 0.97 & -1.64 & 2.16 & $n=181$ \\
\hline & Within & & 0.16 & -1.12 & 0.72 & $\mathrm{~T}-\mathrm{bar}=12.75$ \\
\hline \multirow[t]{3}{*}{ Control of corruption } & Overall & -0.04 & 1.00 & -1.84 & 2.56 & $N=2307$ \\
\hline & Between & & 0.99 & -1.57 & 2.44 & $n=181$ \\
\hline & Within & & 0.18 & -1.01 & 0.87 & $\mathrm{~T}-\mathrm{bar}=12.75$ \\
\hline
\end{tabular}

market size and openness of a host economy. We followed Resmini (2000) and measure the effect of market size by including 'GDP per capita (in 1000 USD PPP)' as a proxy for the actual demand and 'population (in 1000)' for the absolute market size. A common measure in empirical studies for a country's openness is the share of exports plus imports in the GDP (e.g., Economou et al. 2017; Krifa-Schneider and Matei 2010; Loayza et al. 2012). We therefore added the variable 'trade as \% of GDP' as a control variable. Data of all three variables was provided by the World Bank (2017a) (see Table 2).

As the datasets do not include data for all countries in the world, especially not for small islands, such as American Samoa, Cook Islands, nor for all years, especially not for years of war, the constructed unbalanced short panel dataset provides information for 181 countries (the subjects of this analysis) for the years 2003 to 2015, resulting in a sample size of 2307 observations.

\subsection{Methodology}

To answer the question as to whether country-specific factors contribute to explaining the FDI flow into a country, we calculated the unconditional models $\left(\boldsymbol{m}_{0}\right)$, which contain no explanatory variables and estimate the residuals within countries $\left(\boldsymbol{n}_{\boldsymbol{i}}\right)$ as well as the general 
residuals $\left(\varepsilon_{i t}\right)$ separately, for each of the five dependent variables (i.e., overall and sectorspecific FDI inflow):

$$
y_{i t}=\beta_{0}+n_{i}+\varepsilon_{i t}
$$

Next, we calculated the intra-cluster correlations (rho), which represent the unobserved heterogeneity across countries and indicate the estimated proportion of the total variance attributed to differences between countries:

$$
r h o=\frac{\left(s i g m a \_u\right)^{2}}{\left(s i g m a \_u\right)^{2}+\left(s i g m a \_e\right)^{2}}
$$

Here, sigma_u describes the standard deviation of residuals within countries $\left(\boldsymbol{n}_{\boldsymbol{i}}\right)$, while sigma_e describes the overall error term $\left(\varepsilon_{i t}\right)$. The intra-cluster correlation (rho) can take a value $>0$ and $<1$, whereby a high value indicates that the measurements over time within a country are not independent but rather affected by unobserved heterogeneity.

All unconditional models report a significant intra-cluster correlation, indicating FDI inflow is strongly correlated within countries over time and, consequently, influenced by unobserved heterogeneity across countries. This serial autocorrelation is particularly strong for the FDI inflow into manufacturing (0.816), the overall FDI inflow (0.710), and the FDI inflow into creative industries (0.623). A smaller but still significant intra-cluster correlation was estimated for the FDI inflow into tourism (0.482) and construction (0.256).

These results underpin our decision to apply a panel data approach, as performing standard OLS (ordinary least squares) regressions would entail the risk of violating the standard assumption of independent observations, leading to inefficient and biased standard errors (Mizon 1995). In such situations, using between-effects, random-effects, or fixed-effects panel models are preferred. Between-effects models use the cross-sectional information reflected in the average differences between subjects (Genser et al. 2015). In the context of this paper, they allow to estimate differences in countries' expected average FDI inflows based on their average country-specific characteristics (between-subject effect). However, they neither use the time-serial information in the data nor do they control for unobserved heterogeneity across countries. In contrast, fixed-effects and random-effects models are able to model changes within subjects over time and account for unobserved heterogeneity (Rabe-Hesketh and Skrondal 2008). For the purpose of the paper, they allow to study longitudinal effects, estimating the expected change in a country's FDI inflow based on changes in their country-specific characteristics (within-subject effect). While fixed-effects models only allow to estimate the effect of time-varying covariates on the response variable (Rabe-Hesketh and Skrondal 2008), random-effects regressions allow the integration of covariates that do not vary over time (Giesselmann and Windzio 2013). However, randomeffects models are based on more restrictive assumptions than fixed-effects models, e.g., no correlated unobserved unit-specific heterogeneity, leading to biased estimates in the case of violation. Hence, both fixed-effects and random-effects models have their advantages and disadvantages. In this regard, Mundlak (1978) suggests that the virtues of betweeneffects, fixed-effects, and random-effects models can be combined by adding the subjectspecific means of the independent variables to the random-effects model. This so-called hybrid panel model allows to estimate the within- and between-subject effects in a single random-effects model.

After applying a Hausman specification test to compare the random-effects and fixedeffects estimates, which yield a significant result $\left(\operatorname{Prob}>\mathrm{chi}^{2}=0.0180\right)$, we had to refrain from estimating a classic random-effects model (see Table 6). Therefore, we decided to 
follow Mundlak's (1978) suggestion and applied a hybrid panel model, allowing us to directly compare the within- and between-subject effects.

We estimated five hybrid panel regression models, one for each of the dependent variables: overall FDI inflow (m1), FDI inflow into manufacturing (m2), FDI inflow into construction (m3), FDI inflow into tourism (m4), and FDI inflow into creative industries (m5) (see Table 3). The underlying equation of the resulting linear hybrid model is:

$$
y_{i t}=\beta_{0}+\beta\left(x_{i t}-\bar{x}_{i}\right)+\gamma \bar{x}_{i}+\delta z_{i}+n_{i}+\varepsilon_{i t}
$$

In this equation, $y_{i t}$ represents the FDI inflow into country $i$ in year $t$. Here, $\beta$ represents the coefficient of the within-unit component of an explanatory variable $x$. In addition, $\gamma$ represents the coefficient of the between-unit component of an explanatory variable $x$. Moreover, $\delta$ represents the coefficient of the time-constant explanatory variable $z$. Finally, $\beta_{0}$ represents the constant term of the regression. In line with Altay and Ramirez (2010), the model includes a 1-year time lag between the disaster occurrence and FDI inflow in order to acknowledge the time needed for multinational enterprises to complete their decision-making process to invest within a foreign country. We added additional time lag variables (3-year and 5-year) to the fixed-effects model (m6, m7, m8, m9, m10), aiming to gather additional insights into the differences between short-term and long-term effects of natural disasters on FDI inflow (see Table 4). Here, we follow Loayza et al. (2012) and Oh et al. (2020), who argue that economic recovery takes some time and that managers of MNEs might use a longer period to assess the risk level of a country in which to invest.

To ensure that all assumptions of ordinal logistic regressions were met, we tested for multicollinearity between the independent variables, which, with an VIF of 5.36, can be ruled out (see Akinwande et al. 2015). Moreover, the estimated within-subject effects are comparable with those estimated by the classic fixed-effects model (see Table 7), confirming the robustness of the regression model.

\section{Results and discussion}

In the following, we discuss our three hypotheses consecutively based on the statistical effects estimated by the hybrid panel model. Following Gelman and Stern (2006), we interpret the effect of an independent variable if its margin of error is not significantly larger than $10 \%$.

H1 The more a country is affected by natural disasters, the less it attracts FDI.

Based on our findings in $\mathrm{m} 1$, we have to reject our first hypothesis, as, from a crosssectional perspective (between-subject effect), we do not find a statistically significant relationship between the average number of people affected by natural disasters in a country and the average overall FDI inflow into this country $(P>|z|=0.294)$. While the small number of existing studies (e.g., Anuchitworawong and Thampanishvong 2015; Escaleras and Register 2011; Khan et al. 2020) has found a negative effect of natural disasters on FDI, our findings do not support these results. In this context, it is important to note that our study differs in two respects from the above: First, it uses the number of affected people in order to consider the severity of natural disasters, while the only comprehensive studies by Escaleras and Register (2011) and Khan et al. (2020) taking into account a large number of countries rest on the number of events. Second, 


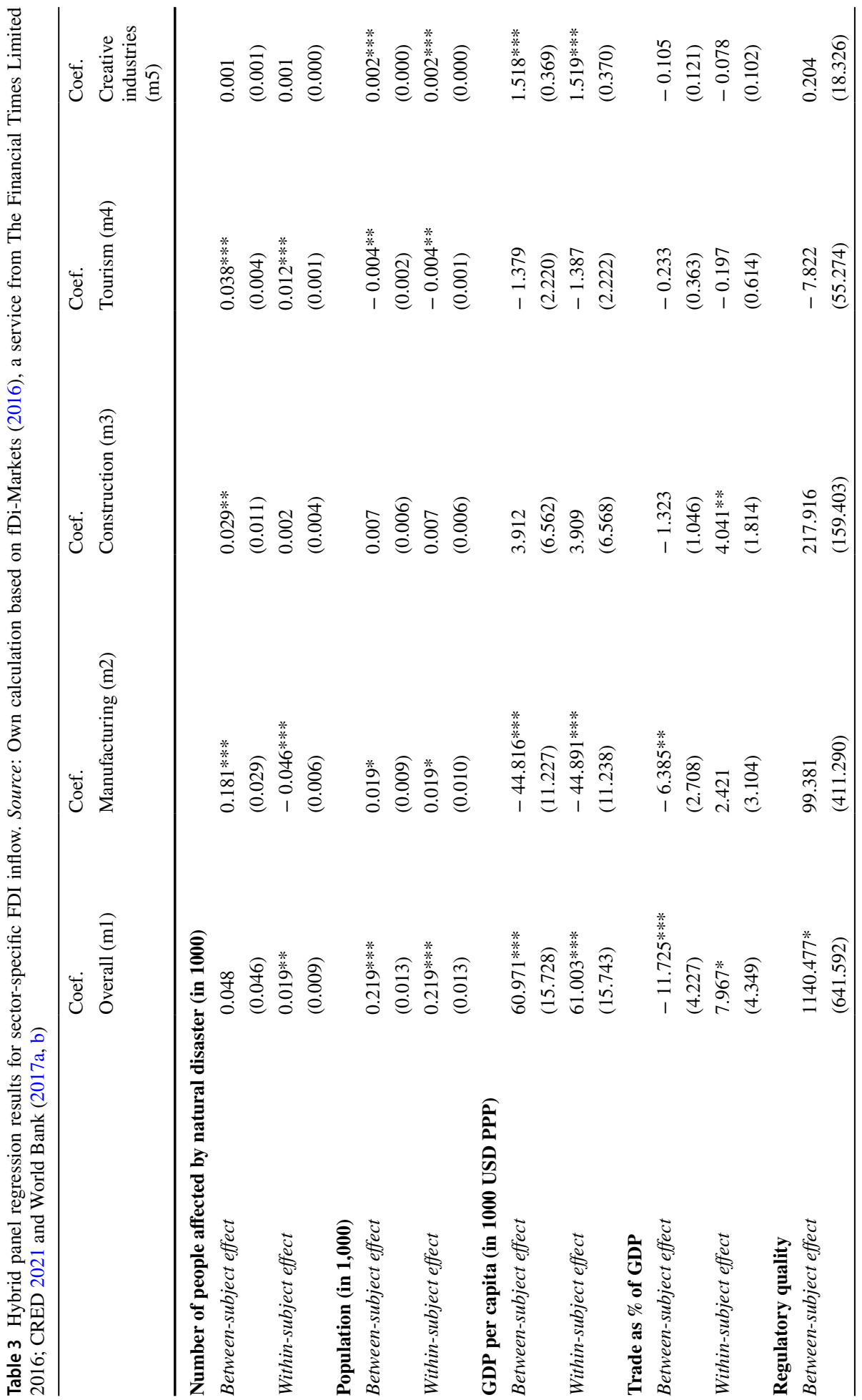




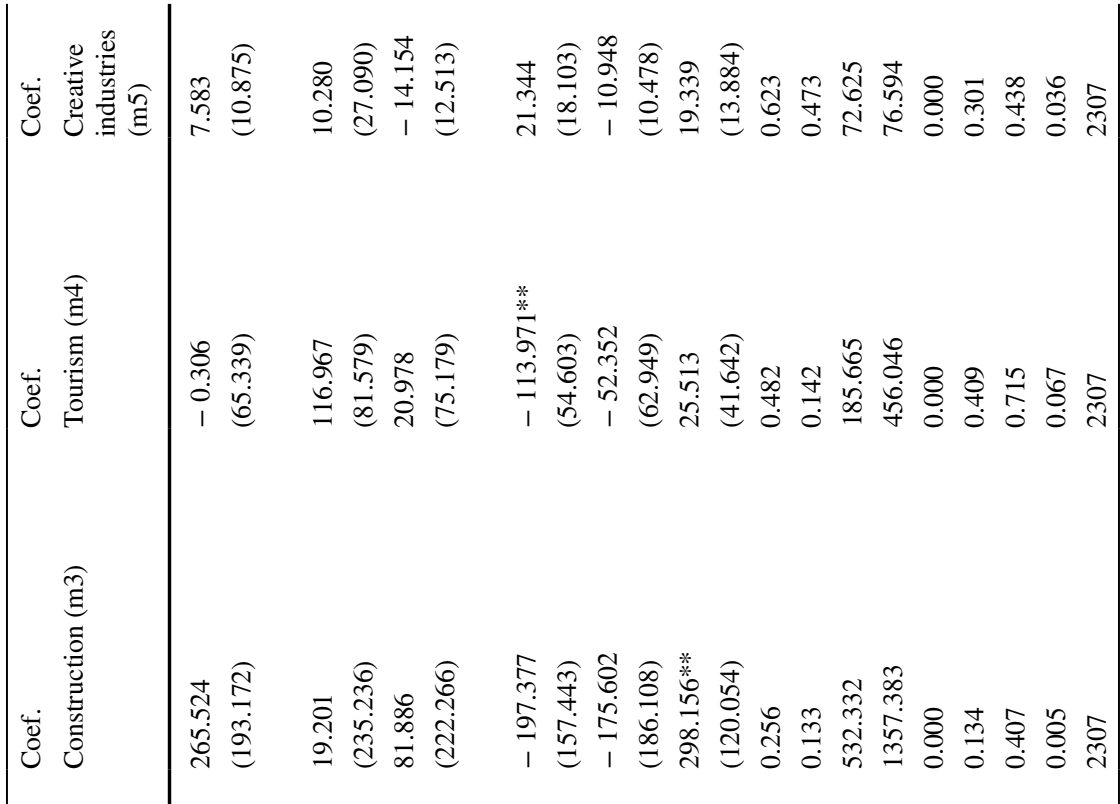

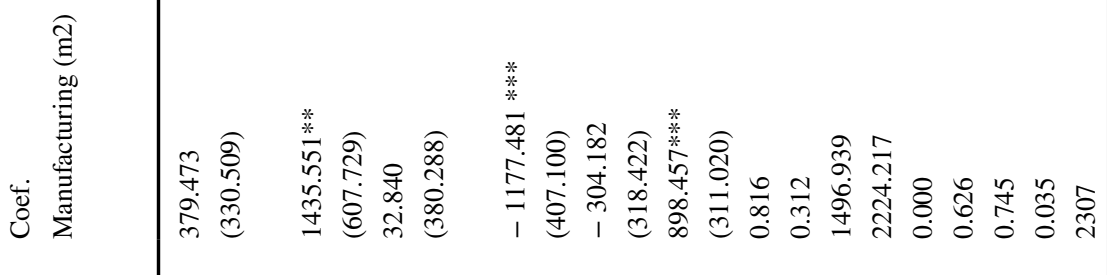

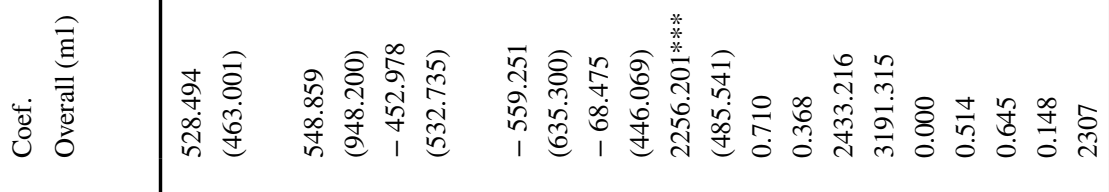

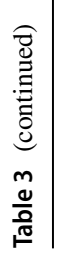
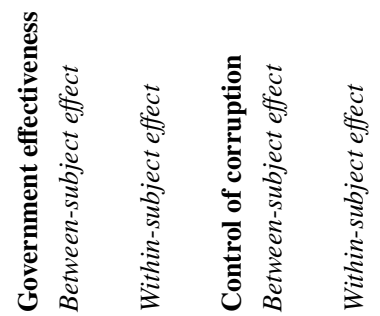

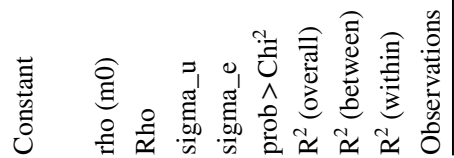




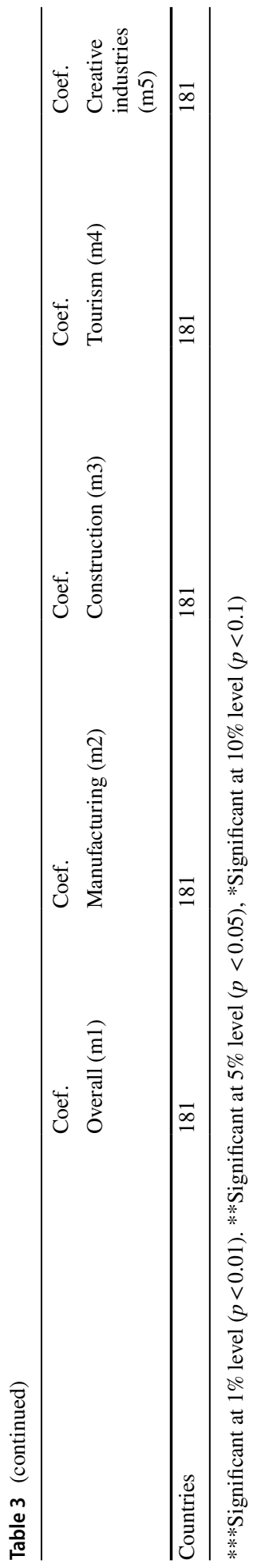


this study consists of a sample of 181 countries and therefore differs from Escaleras and Register's study (2011) encompassing 94 countries and Khan's et al. (2020) study of 55 Belt and Road Initiative countries.

H2 The effect of natural disasters on FDI attraction varies among different economic sectors.

Although the general model $(\mathrm{m} 1)$ does not reveal a significant cross-sectional effect of the average number of people affected by natural disasters in a country on its average overall FDI inflow, the sector-specific models (m2-m5) reveal a more differentiated picture. Here, we find a positive effect of the number of people affected by natural disasters on FDI inflows in the manufacturing (m2), construction (m3), and tourism sector (m4). The findings suggest that with every additional 1000 people affected by natural disasters the average FDI inflow into manufacturing increases significantly by 0.181 million USD, while the average FDI inflow into tourism increases significantly by 0.038 million USD, and the average FDI inflow into construction increases significantly by 0.029 million USD. In contrast, there is no significant effect revealed with regard to FDI inflows into creative industries $(P>|z|=0.274)$. These results confirm our second hypothesis, showing that the effect of natural disasters on FDI attraction varies among different economic sectors. This shows that taking a sector-specific perspective allows uncovering the more nuanced effects of natural disasters on FDI inflows. These findings reflect that investment decisions across various economic sectors are characterized by different features such as sunk costs, volatility of demand, territoriality, resiliency of supply chains (e.g., speed and reliability) and, thus, follow different rationales in dealing with natural disaster risks (Hallegatte 2014; Wilbanks et al. 2007).

The analysis demonstrates the strongest positive effect of countries' exposure to natural disasters on the FDI inflow into the manufacturing sector. It seems that foreign investors assess positively the general large market opportunities of the host country and might not be distracted from the threat of destroyed capital due to natural disasters.

The positive effect of the severity of natural disasters on FDI related to construction can be explained through the rapid demand surge as part of the rebuilding process after a natural disaster occurred (Hallegatte 2014; Rose 2009). Rather than seeing natural disasters as a business disadvantage, they can be seen as a business opportunity in the construction sector, leading to higher FDI in disaster-prone countries.

The positive effect on FDI in the tourism sector can be supported by case study evidence. While the Boxing Day Tsunami of 2004 had a direct negative effect on tourist arrivals in destinations like the Maldives or the Thai region of Phang Nga, subsequent investments in rebuilding touristic facilities led to a rapid recovery in terms of accommodation capacities (Carlsen and Hughes 2008; Willroth et al. 2012). This indicates that investors in the tourism sector are not discouraged from investing in disaster-prone countries despite the risk of short-term declines of tourist arrivals after a natural disaster took place. This investment behavior suggests that investors consider the longterm location advantages (e.g., loyal customers, unique landscape) even of hazard-prone locations such as the Dominican Republic.

In contrast to these significant effects, the insignificant impact of countries' exposure to natural disasters on the FDI inflow in the creative industries sector reflects the footloose character of this sector. The finding indicates that natural disaster risks are not perceived as a significant determinant of location choice for FDI in this sector. 
H3 The longitudinal effect of natural disasters on the attraction of FDI significantly differs from the cross-sectional effect.

While existing studies, as well as our previous models, studied the relationship between natural disasters and FDI inflow from a cross-sectional perspective (betweensubject effect), taking a longitudinal perspective (within-subject effect) reveals novel insights into this relationship from a causal disaster-reaction perspective. From a longitudinal perspective, our results estimated by the hybrid model (m1) suggest that if the number of people affected by natural disasters increases by 1000 in a given country, the overall FDI inflow into this country increases significantly by 0.019 million USD in the following year (within-subject effect). However, when adding the 3-year and 5-year time lag to the fixed-effects model (m6; cf. Table 4), the effect of the 1-year time lag turns negative, while the effects of 3-year and 5-year time lag remain positive. Our results estimated by the fixed-effects model (m6) show that if the number of people affected increases by 1000 in a given country, the overall FDI inflow into this country decreases significantly by 0.054 million USD in the following year, while it increases significantly by 0.084 million USD 3 years and by 0.035 million USD three 5 years afterward. This result confirms our third hypothesis, revealing that the longitudinal effect of natural hazards on the attraction of FDI significantly differs from the cross-sectional effect. This finding can be interpreted as companies refraining from investing in the direct aftermath of natural disasters but investing all the more in the medium and long term. The negative effect of natural disasters on FDI inflows 1 year after an event is in line with the findings from Anuchitworawong and Thampanishvong (2015), Escaleras and Register (2011), and Khan et al. (2020). The negative short-term effect can be explained by risk aversion of MNEs (cf. Khan et al. 2020; UNCTAD 2017b). The positive mid- and long-term relationship can be explained by changes in the marginal product of capital after natural disaster. As the destruction of physical capital, caused by a natural disaster, decreases the stock of physical capital, the marginal product of capital increases, resulting in an increase in the return of capital provision. MNEs are likely to react to this change with increasing FDI when the first recovery phase is over (Crespo Cuaresma et al. 2008). Here, we can confirm the effect of 'creative destruction' that takes place after disaster events (e.g., Crespo Cuaresma et al. 2008; Skidmore and Toya 2002), but it is not initiated immediately after a disaster event.

In addition, the positive effect might be linked to governmental agencies and private investors learning and adapting in order to cope with natural disasters (Solecki et al. 2017). Typically, MNEs anticipate natural disasters and invest in more emergency response activities, such as training the staff, integrate back-up facilities, and strengthen their building fabrics to relieve the economic losses of future disaster events (Neise et al. 2018). This shows that exposure to natural disasters per se cannot explain lacking FDI inflow. It rather points to the significance of adapting to these natural conditions since disaster-prone locations hold other locational advantages, such as abundant skilled labor force or a high market potential that might offset the disaster proneness. 


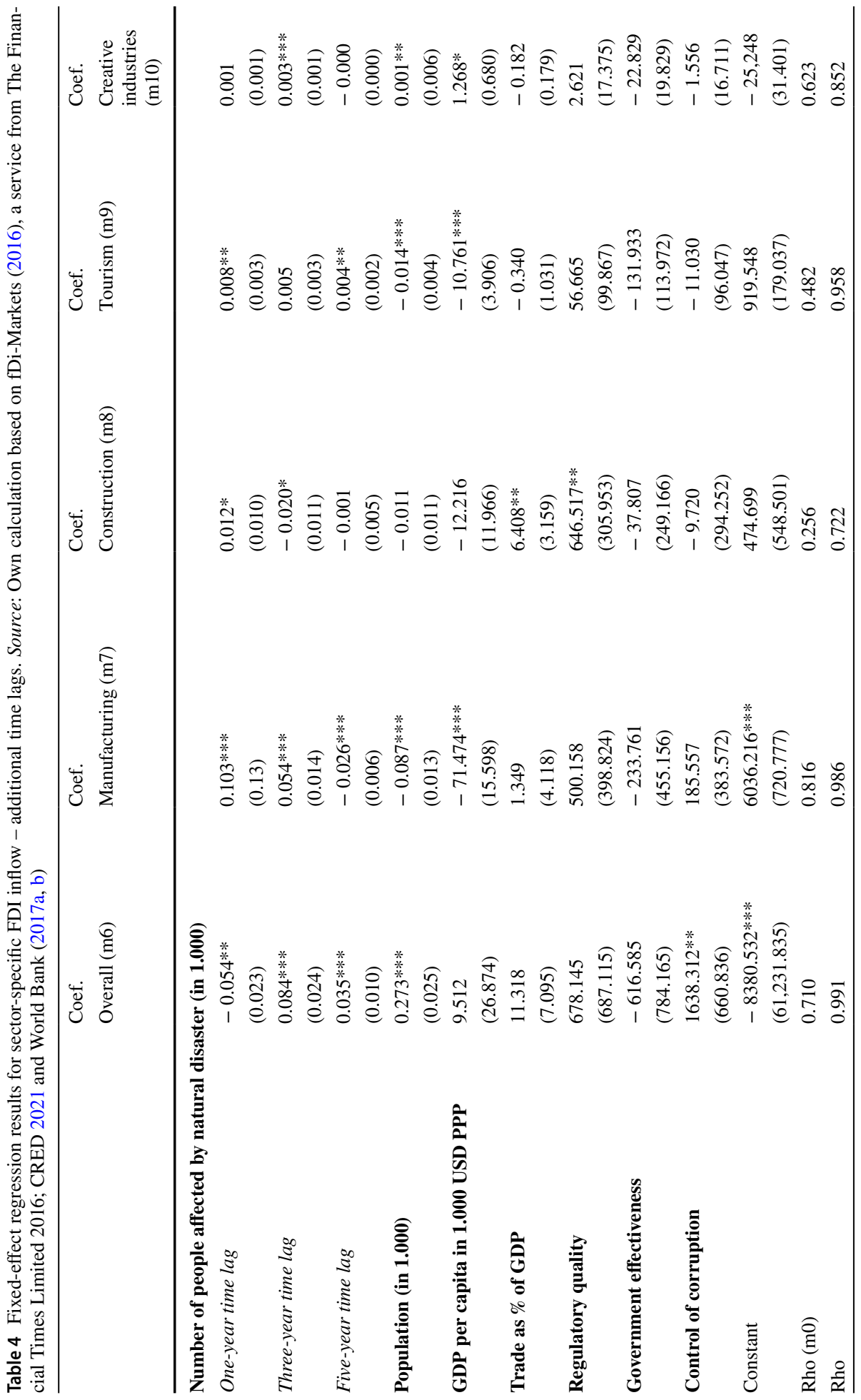




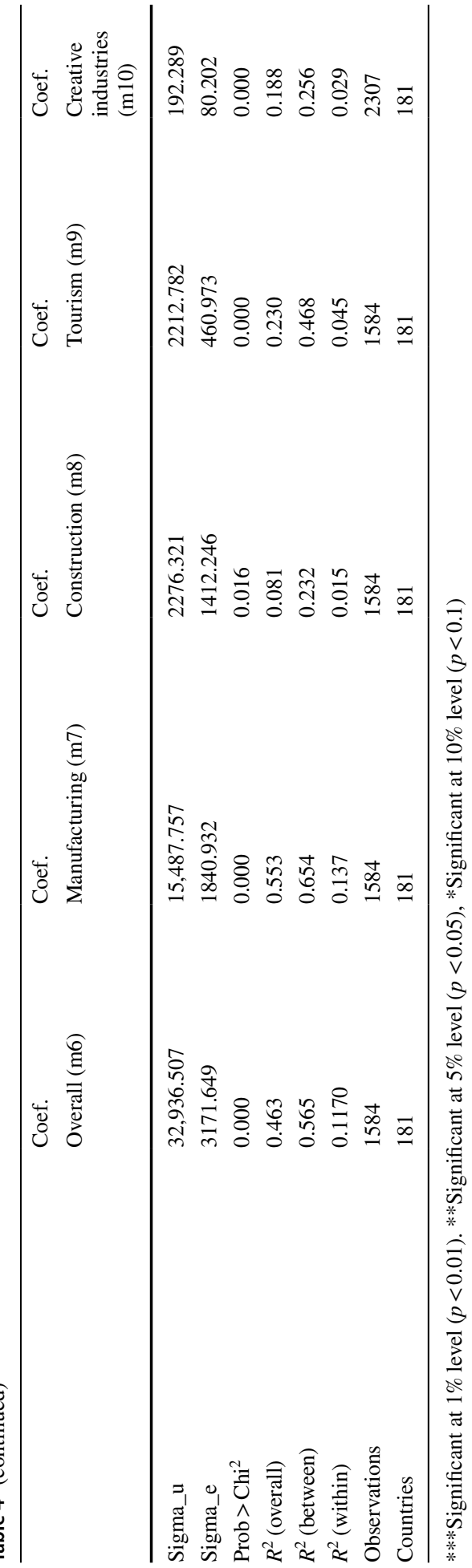




\section{Concluding remarks}

The paper aimed to analyze the yet complex relationship between a country's exposure to natural disasters and its ability to attract FDI. To this aim, we deployed hybrid panel regressions for a dataset of 181 countries over a period of 13 years (2003-2015) across four different economic sectors (manufacturing, construction, tourism, and creative industries). The analysis yields two important results: First, the findings of the analysis show that the effect of natural disasters on FDI attraction varies among different economic sectors. We find a positive effect of natural disasters on FDI inflows in the manufacturing, construction, and tourism sector, whereas FDI in the more footloose creative industries seems not to be affected by the occurrence of natural disasters. Second, the results demonstrate that the longitudinal effect of natural disasters on the attraction of FDI inflows differs from the cross-sectional effect. Although we can confirm the negative short-term effect of natural disasters on overall FDI inflow, the overall FDI inflow increases 3 and 5 years after a disaster event.

On a conceptual level, these findings highlight the complex nature that characterizes the relationship between natural disasters and FDI inflow. The direction of effect must not be seen as equal across different industries. While we are still standing at the beginning of exploring this relationship, these findings point to the need for a differentiated assessment which has to be incorporated in the data selection and the model specification. This could be further advanced in future studies, by assessing the factors that shape the longitudinal effect of natural disasters on FDI inflows, such as disaster relief services, government effectiveness, regulatory quality, and the availability of insurance services.

On a theoretical level, the study contributes to the empirical literature strand that applies the OLI model. The focus on the effect of natural disasters in this study complements the existing understanding where MNEs invest abroad. Whether positive or negative, the results of the study suggest that the severity of natural disasters constitutes a critical locational factor that exerts an influence on the investment decision of MNEs.

Although the analysis provides a new perspective on how natural disasters determine FDI inflow, it demands further research. Especially due to the globally forecasted increase in the number and intensity of natural disaster events due to climate change (IPCC 2018) and the need to further accelerate economic development in many countries of the world, it is necessary to gain a deeper understanding of the relationship between natural disasters and FDI inflows. In this regard, the revealed sector-specific effects require further insights into the location decisions of MNEs across different industries in the context of natural disasters. A more qualitative approach including in-depth interviews with representatives of MNEs might be promising for this endeavor. Furthermore, scenario approaches (e.g., using factorial surveys) that assess the judgments of MNEs according to various business risks, institutional settings, and countries' exposure to natural disasters would allow identifying the factors that influence the longitudinal effect of natural disasters on FDI inflows.

\section{Appendix}

See Tables 5, 6, and 7. 
Table 5 Taxonomy of the selected economic sectors according to the fDi-markets database. (Source: fDi markets)

\begin{tabular}{ll}
\hline Sector & Definition \\
\hline Construction & $\begin{array}{l}\text { Real estate and building, construction materials, construction machinery \& equipment, } \\
\text { building products and parts }\end{array}$ \\
Manufacturing & $\begin{array}{l}\text { Production or processing of any good, such as manufacturing plants, processing plants, } \\
\text { production facilities, smelters, assembly facilities }\end{array}$ \\
Tourism & $\begin{array}{l}\text { Hotels, tourism, leisure \& entertainment (no retail) } \\
\text { Creative industries }\end{array}$ \\
$\begin{array}{l}\text { Digital media, media, multi-media, video games, education, training, publishing, news, } \\
\text { printing, music, design services, film, broadcasting, TV, architecture, advertising, } \\
\text { market research, PR, theater, cinema }\end{array}$
\end{tabular}

Table 6 Hausman specification test

\begin{tabular}{l|cccc} 
& $\begin{array}{c}\text { Coefficients } \\
\text { fixed }\end{array}$ & $\begin{array}{c}(B) \\
\text { random }\end{array}$ & $\begin{array}{c}(\mathrm{b}-\mathrm{B}) \\
\text { Difference }\end{array}$ & $\begin{array}{c}\text { sqrt(diag(V_b-V_B )) } \\
\text { S.E. }\end{array}$ \\
\hline AffectedDe h & .0188391 & -.039204 & .058043 & .0035929 \\
Populationt1 & .2193477 & .0372785 & .1820692 & .0128185 \\
GDPpercapi 1 & 60.99722 & 61.59795 & -.6007264 & 9.579064 \\
TradeofGDPt1 & $\mathbf{7 . 9 6 6 0 7 2}$ & 1.626743 & 6.339329 & 2.507605 \\
Regulatory 1 & $\mathbf{5 2 8 . 5 2 9 1}$ & $\mathbf{9 7 6 . 2 6 4 2}$ & -447.7351 & 219.018 \\
Government 1 & -453.0652 & -433.402 & -19.66324 & 221.0719 \\
Corruptiont1 & -68.32883 & -200.275 & 131.9461 & 209.4494 \\
\hline
\end{tabular}

$\mathrm{b}=$ consistent under $\mathrm{Ho}$ and $\mathrm{Ha}$; obtained from $x$ treg

Test: Ho: difference in coefficients not systematic

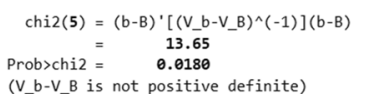


Table 7 Fixed-effect regression results for sector-specific FDI inflow

\begin{tabular}{|c|c|c|c|c|c|}
\hline & $\begin{array}{l}\text { Coef. } \\
\text { Overall }\end{array}$ & $\begin{array}{l}\text { Coef. } \\
\text { Manufacturing }\end{array}$ & $\begin{array}{l}\text { Coef. } \\
\text { Construction }\end{array}$ & $\begin{array}{l}\text { Coef. } \\
\text { Tourism }\end{array}$ & $\begin{array}{l}\text { Coef. } \\
\text { Creative industries }\end{array}$ \\
\hline \multirow{2}{*}{$\begin{array}{l}\text { Number of people } \\
\text { affected by natural } \\
\text { disaster (in 1.000) }\end{array}$} & $0.019 * *$ & $0.046 * * *$ & 0.002 & $0.012 * * *$ & 0.000 \\
\hline & $(0.009)$ & $(0.006)$ & $(0.004)$ & $(0.001)$ & $(0.000)$ \\
\hline \multirow[t]{2}{*}{ Population (in 1.000) } & $0.219 * * *$ & $0.019 * *$ & 0.007 & $-0.004 * *$ & $0.002 * * *$ \\
\hline & $(0.013)$ & $(0.009)$ & $(0.006)$ & $(0.002)$ & $(0.000)$ \\
\hline \multirow{2}{*}{$\begin{array}{l}\text { GDP per capita in } 1.000 \\
\text { USD PPP }\end{array}$} & $60.997 * * *$ & $-44.893 * * *$ & 3.907 & -1.388 & $1.519 * * *$ \\
\hline & $(15.365)$ & $(10.709)$ & $(6.536)$ & $(2.196)$ & $(0.369)$ \\
\hline \multirow[t]{2}{*}{ Trade as $\%$ of GDP } & $7.966^{*}$ & 2.420 & $4.041 * *$ & -0.197 & -0.078 \\
\hline & $(4.244)$ & $(2.958)$ & $(1.805)$ & $(0.607)$ & $(0.102)$ \\
\hline \multirow[t]{2}{*}{ Regulatory quality } & 528.529 & 379.445 & 265.508 & -0.322 & 7.583 \\
\hline & $(451.888)$ & $(314.957)$ & (192.211) & $(64.578)$ & $(10.846)$ \\
\hline \multirow{2}{*}{$\begin{array}{l}\text { Government effective- } \\
\text { ness }\end{array}$} & -453.065 & 32.850 & 81.902 & 20.994 & -14.154 \\
\hline & $(519.948)$ & $(362.393)$ & $(221.160)$ & $(74.305)$ & $(12.480)$ \\
\hline \multirow[t]{2}{*}{ Control of corruption } & -68.329 & -304.128 & -175.579 & -52.340 & -10.947 \\
\hline & $(435.363)$ & $(303.439)$ & $(185.182)$ & $(62.217)$ & $(10.449)$ \\
\hline \multirow[t]{2}{*}{ Constant } & $-7180.683 * * *$ & $1445.584 * * *$ & -288.877 & 363.098 & $-63.978 * * *$ \\
\hline & $(643.954)$ & $(448.823)$ & (273.906) & $(455.941)$ & $(15.456)$ \\
\hline Rho (m0) & 0.710 & 0.816 & 0.256 & 0.482 & 0.623 \\
\hline Rho & 0.985 & 0.658 & 0.276 & 0.797 & 0.913 \\
\hline Sigma_u & $25,991.816$ & 3087.463 & 837.223 & 901.940 & 248.352 \\
\hline Sigma_e & 3190.456 & 2223.685 & 1357.060 & 455.941 & 76.576 \\
\hline Prob $>\mathrm{Chi}^{2}$ & 0.000 & 0.000 & 0.000 & 0.000 & 0.000 \\
\hline$R^{2}$ (overall) & 0.441 & 0.5131 & 0.116 & 0.210 & 0.204 \\
\hline$R^{2}$ (between) & 0.686 & 0.6084 & 0.354 & 0.498 & 0.304 \\
\hline$R^{2}$ (within) & 0.149 & 0.0351 & 0.005 & 0.067 & 0.036 \\
\hline Observations & 2307 & 2307 & 2307 & 2307 & 2307 \\
\hline Countries & 181 & 181 & 181 & 181 & 181 \\
\hline
\end{tabular}

Funding Open Access funding enabled and organized by Projekt DEAL. The research was funded by the German Research Foundation (Deutsche Forschungsgemeinschaft-DFG) within the framework of the German Excellence Initiative.

\section{Declarations}

Conflict of interest The authors declared no potential conflicts of interest with respect to the research, authorship, and/or publication of this article.

Open Access This article is licensed under a Creative Commons Attribution 4.0 International License, which permits use, sharing, adaptation, distribution and reproduction in any medium or format, as long as you give appropriate credit to the original author(s) and the source, provide a link to the Creative Commons licence, and indicate if changes were made. The images or other third party material in this article are included in the article's Creative Commons licence, unless indicated otherwise in a credit line to the material. If material is not included in the article's Creative Commons licence and your intended use is not 
permitted by statutory regulation or exceeds the permitted use, you will need to obtain permission directly from the copyright holder. To view a copy of this licence, visit http://creativecommons.org/licenses/by/4.0/.

\section{References}

Akinwande M, Dikko H, Samson A (2015) Variance inflation factor: as a condition for the inclusion of suppressor variable(s) in regression analysis. Open J Stat 5:754-767

Alam A, Zulfiqar Ali Shah S (2013) Determinants of foreign direct investment in OECD member countries. J Econ Stud 40:515-527

Albala-Bertrand JM (1993) Political economy of large natural disasters: with special reference to developing countries. Clarendon Press, Oxford

Alfaro L, Chanda A, Kalemli-Ozcan S, Sayek S (2004) FDI and economic growth: the role of local financial markets. J Int Econ 64:89-112

Alfaro L, Chanda A, Kalemli-Ozcan S, Sayek S (2010) Does foreign direct investment promote growth? Exploring the role of financial markets on linkages. J Dev Econ 91:242-256

Al-Sadig A (2009) The effects of corruption on FDI inflows. Cato J 29:267-294

Altay N, Ramirez A (2010) Impact of disasters on firms in different sectors: implications for supply chains. J Supply Chain Manag 46:59-80

Anuchitworawong C, Thampanishvong K (2015) Determinants of foreign direct investment in Thailand: does natural disaster matter? Int J Disaster Risk Reduct 14:312-321

Asiedu E (2006) Foreign direct investment in Africa: the role of natural resources, market size, government policy, institutions and political instability. World Econ 29:63-77

Bevan AA, Estrin S (2004) The determinants of foreign direct investment into European transition economies. J Comp Econ 32:775-787

Bhandari R, Dhakal D, Pradhan G, Upadhyaya K (2007) Foreign aid, FDI and economic growth in East European Countries. Econ Bullet 6:1-9

Blomström M, Lipsey RE (1989) The export performance of U.S. and Swedish Multinationals. Rev Income Wealth 35:245-264

Blonigen BA (2005) A review of the empirical literature on FDI determinants. Atl Econ J 33:383-403

Burger MJ, van der Knaap B, Wall RS (2013) Revealed competition for greenfield investments between European regions. J Econ Geogr 13:619-648

Bwalya SM (2006) Foreign direct investment and technology spillovers: evidence from panel data analysis of manufacturing firms in Zambia. J Dev Econ 81:514-526

Carlsen JC, Hughes M (2008) Tourism market recovery in the Maldives after the 2004 Indian Ocean Tsunami. J Travel Tour Mark 23:139-149

Cavallo E, Galiani S, Noy I, Pantano J (2013) Catastrophic natural disasters and economic growth. Rev Econ Stat 95:1549-1561

Chen S (2017) Profiting from FDI in conflict zones. J World Bus 52:760-768

Cleeve EA (2008) How effective are fiscal incentives to attract FDI Sub-Saharan Africa? J Dev Areas 42:135-153

CRED (2021) EM-DAT: the emergency events database. Brussels

Crespo Cuaresma J, Hlouskova J, Obersteiner M (2008) Natural disasters as creative destruction? Evidence from developing countries. Econ Inq 46:214-226

Cunado J, Ferreira S (2014) The macroeconomic impacts of natural disasters: The case of floods. Land Econ 90:149-168

Damgaard J (2011) Productivity spillovers from FDI: Ownership structures, domestic firm characteristics, and FDI characteristics. Danmarks Nationalbank working papers, vol 72, Danmarks Nationalbank, Copenhagen

Dicken P (2015) Global shift: mapping the changing contours of the world economy, 7th edn. Sage, Los Angeles

Djalante R, Garschagen M (2017) A review of disaster trend and disaster risk governance in Indonesia: 1900-2015. In: Djalante R, Garschagen M, Thomalla F, Shaw R (eds) Disaster risk reduction in Indonesia-progress, challenges, and issues. Springer, Cham, pp 21-56

Driffield N, Taylor K (2000) FDI and the labour market: a review of the evidence and policy implications. Oxford Rev Econ Pol 16:90-103

Dunning JH (1977) Trade, location of economic activity and the MNE: a search for an eclectic approach. In: Ohlin B, Hesselborn PO, Wijkman PM (eds) The international allocation of economic activity. Palgrave Macmillan, London, pp 395-418 
Economou F, Hassapis C, Philippas N, Tsionas M (2017) Foreign direct investment determinants in OECD and developing countries. Rev Dev Econ 21:527-542

Escaleras M, Register CA (2011) Natural disasters and foreign direct investment. Land Econ 87:346-363

fDi Markets (2016) A service from the financial times limited 2016. Financial Times, London

Felbermayr G, Gröschl J (2014) Naturally negative: the growth effects of natural disasters. J Dev Econ 111:92-106

Gedik AM (2013) Determinants of foreign direct investment for OECD countries: evidence from dynamic panel data analysis. Brit J Econ Finance Manag Sci 7:119-140

Gelman A, Stern H (2006) The difference between "Significant" and "Not Significant" is not itself statistically significant. Am Stat 60:328-331

Genser B, Teles CA, Barreto ML, Fischer JE (2015) Within- and between-group regression for improving the robustness of causal claims in cross-sectional analysis. Environ Health 14:60

Giesselmann M, Windzio M (2013) Regressionsmodelle zur Analyse von Paneldaten. Studienskripten zur Soziologie. Springer, Dordrecht

Girma S, Greenaway D, Wakelin K (2001) Who benefits from foreign direct investment in the UK? Scot J Polit Econ 48:119-133

Girma S, Wakelin K (2002) Are there regional spillovers from FDI in the UK? In: Greenaway D, Upward $\mathrm{R}$, Wakelin K (eds) Trade, investment, migration and labour market adjustment. Palgrave Macmillan, London, pp 172-186

Görg H, Greenaway D (2004) Much ado about nothing? Do domestic firms really benefit from foreign direct investment? World Bank Res Obser 19:171-197

Hallegatte S (2014) Natural disasters and climate change. Springer, Cham

Helpman E, Melitz MJ, Yeaple SR (2004) Export versus FDI with heterogeneous firms. Am Econ Rev 94:300-316

IPCC (2018) Global Warming of $1.5^{\circ} \mathrm{C}$. An IPCC Special Report on the impacts of global warming of $1.5{ }^{\circ} \mathrm{C}$ above pre-industrial levels and related global greenhouse gas emission pathways, in the context of strengthening the global response to the threat of climate change, sustainable development, and efforts to eradicate poverty. IPCC, Geneva

Jadhav P, Katti V (2012) Institutional and political determinants of foreign direct investment: evidence from BRICS economies. Poverty Public Policy 4:49-57

Keen, M., Freeman, P. K., Mani, M. (2003) Dealing with increased risk of natural disasters: Challenges and options. IMF Working Paper No. 03/197. https://doi.org/10.5089/9781451860030.001

Khan A, Chenggang Y, Khan G, Muhammad F (2020) The dilemma of natural disasters: Impact on economy, fiscal position, and foreign direct investment alongside Belt and Road Initiative countries. Sci Total Environ 743:140578

Klomp J, Valckx K (2014) Natural disasters and economic growth. A meta-analysis. Global Environ Change 26:183-195

Krifa-Schneider H, Matei I (2010) Business climate, political risk and FDI in developing countries: evidence from panel data. Int J Econ Finance 2:54-65

Linnenluecke MK, Griffiths A (2015) The climate resilient organization: adaptation and resilience to climate change and weather extremes. Edward Elgar, Cheltenham

Liu X, Gao L, Lu J, Lioliou E (2016) Environmental risks, localization and the overseas subsidiary performance of MNEs from an emerging economy. J World Bus 51:356-368

Loayza NV, Olaberría E, Rigolini J, Christiaensen L (2012) Natural disasters and growth: going beyond the averages. World Dev 40:1317-1336

McDonald F, Tüselmann HJ, Heise A, Williams D (2003) Employment in host regions and foreign direct investment. Environ Plan C Gov Policy 21:687-701

Mizon GE (1995) A simple message for autocorrelation correctors: don't. J Econom 69:267-288

Mundlak Y (1978) On the pooling of time series and cross section data. Econometrica 46:69-85

Munich RE (2017) NatCatSERVICE: Relevant natural loss events worldwide 2002-2016, Munich

Neise T, Revilla Diez J (2019) Adapt, move or surrender? Manufacturing firms' routines and dynamic capabilities on flood risk reduction in coastal cities of Indonesia. Int J Disaster Risk Reduct 33:332-342

Neise T, Revilla Diez J, Garschagen M (2018) Firms as drivers of integrative adaptive regional development in the context of environmental hazards in developing countries and emerging economies-a conceptual framework. Environ Plan C Gov Policy 36:1522-1542

Nohrstedt D, Mazzoleni M, Parker CF, Di Baldassarre G (2021) Exposure to natural hazard events unassociated with policy change for improved disaster risk reduction. Nat Commun 12:193

Noy I (2009) The macroeconomic consequences of disasters. J Dev Econ 88:221-231 
Oh CH, Oetzel J, Rivera J, Lien D (2020) Natural disasters and MNC subnational investments in China. Multinatl Bus Rev 28:245-274

Rabe-Hesketh S, Skrondal A (2008) Multilevel and longitudinal modeling using Stata, 2nd edn. Stata Press Publication, College Station

Raschky PA (2008) Institutions and the losses from natural disasters. Nat Hazard Earth Sys 8:627-634

Resmini L (2000) The determinants of foreign direct investment in the CEECs: new evidence from sectoral patterns. Econ Transit 8:665-689

Rose A (2009) Economic Resilience to Disasters. CARRI Research Report, Los Angeles

Schumacher I, Strobl E (2011) Economic development and losses due to natural disasters: the role of hazard exposure. Ecol Econ 72:97-105

Skidmore M, Toya H (2002) Do natural disasters promote long-run growth? Econ Inq 40:664-687

Solecki W, Pelling M, Garschagen M (2017) Transitions between risk management regimes in cities. Ecol Soc 22:38

Swiss Re Institue (2017) Natural catastrophes and man-made disasters in 2016: a year of widespread damages. Zurich

Tondl G, Fornero JA (2010) Sectoral productivity and spillover effects of FDI in Latin America. FIW Working Paper, vol 53, FIW, Wien

Tsai C-H, Wu T-C, Wall G, Linliu S-C (2016) Perceptions of tourism impacts and community resilience to natural disasters. Tourism Geogr 18:152-173

UNCTAD (2017a) Foreign direct investment: inward and outward flows and stock, annual, 1970-2016. Accessed on http://unctadstat.unctad.org/wds/ReportFolders/reportFolders.aspx

UNCTAD (2017b) World Investment Report 2017: investment and the digital economy. United Nations Publication, vol. 2017, New York and Geneva, United Nations.

Wang M, Wong MCS (2009) What drives economic growth? The case of cross-border M\&A and greenfield FDI activities. Kyklos 62:316-330

Wang P, Zhang H, Wood J (2021) Foreign direct investment, natural disasters, and economic growth of host countries. In: Chaiechi T (ed) Economic effects of natural disasters. Theoretical Foundations, Methods, and Tools. Academic Press. https://doi.org/10.1016/B978-0-12-817465-4.00007-8

Wilbanks TJ, Romero-Lankao P, Bao M, Berkhout F, Cairncross S, Ceron J-P, Kapshe M, Muir-Wood R, Zapata-Marti R (2007) Industry, settlement and society. In: Parry ML, Canziani OF, Palutikof JP, van der Linden PJ, Hanson CE (eds.), Climate Change 2007: impacts, adaptation and vulnerability. Contribution of Working Group II to the Fourth Assessment Report of the Intergovernmental Panel on Climate Change, Cambridge University Press, Cambridge, pp 357-390

Willroth P, Massmann F, Wehrhahn R, Revilla Diez J (2012) Socio-economic vulnerability of coastal communities in southern Thailand: the development of adaptation strategies. Nat Hazards Earth Syst Sci 12:2647-2658

World Bank (2017a) Indicators. https://data.worldbank.org/indicator?tab=all

World Bank (2017b) Worldwide Governance Indicators. http://info.worldbank.org/governance/wgi/ index.aspx\#doc

World Bank (2020) Resilient industries: competitiveness in the face of disasters. World Bank, Washington

Yasar M, Morrison Paul CJ (2007) Firm performance and foreign direct investment: evidence from transition economies. Econ Bullet 15:1-11

Zhang KH (2001) How does foreign direct investment affect economic growth in China? Econ Transit 9:679-693

Publisher's Note Springer Nature remains neutral with regard to jurisdictional claims in published maps and institutional affiliations. 